\title{
PENEGAKAN HUKUM TERHADAP KEPEMILIKAN TANAH INDONESIA OLEH WARGA NEGARA ASING MELALUI PERJANJIAN NOMINEE
}

\author{
Fithrah, Kejaksaan Negeri Lahat, Sumatera Selatan, e-mail: fithrah@yahoo.com \\ doi: https://doi.org/10.24843/KS.2020.v08.i12.p04
}

\begin{abstract}
ABSTRAK
Tujuan penulisan karya ilmiah ini adalah untuk mengkaji pengaturan terkait kepemilikan tanah di Indonesia oleh orang asing melalui perjanjian nominee dan upaya penegakan hukumnya. Metode penelitian yang digunakan ialah metode penelitian hukum normatif dengan menggunakan pendekatan peraturan perundang-undangan dan konseptual. Hasil dari penulisan karya ilmiah ini ialah penegakan hukum terhadap praktek kepemilikan tanah oleh orang asing melalui perjanjian nominee dapat dilakukan oleh kejaksaan selaku organ negara yang mewakili kepentingan publik, baik melalui sarana perdata maupun pidana. Hal ini perlu dilakukan guna melindungi tanah Indonesia dimiliki oleh orang asing dan guna mendukung upaya negara mewujudkan tugas konstitusionalnya, yakni menguasai tanah bagi sebesar-besarnya kesejahteraan rakyat tanpa harus memberikan ketidakadilan bagi Warga Negara Asing.
\end{abstract}

Kata Kunci: Penegakan Hukum, Hak Atas Tanah, Warga Negara Asing

\section{ABSTRACT}

The purpose of writing this scientific paper is to examine regulations related to land ownership in Indonesia by foreigners through nominee agreements and law enforcement efforts. The research method used is normative legal research methods using statute and conceptual approaches. The result of writing this scientific paper is that law enforcement against the practice of land ownership by foreigners through nominee agreements can be carried out by the prosecutor as the state organ representing the public interest, both through civil and criminal means. This needs to be done in order to protect Indonesian land owned by foreigners and to support the state's efforts to realize its constitutional duties, namely to control the land for the maximum welfare of the people without having to give injustice to foreign citizens.

Key Words: Law Enforcement, Land Rights, Foreign Citizens

\section{Pendahuluan}

\subsection{Latar Belakang}

Secara konstitusional Undang-Undang Dasar Negara Republik Indonesia Tahun 1945 (UUD 1945) pada Pasal 33 ayat (3), mengatur dan menegaskan bahwa negara menguasai keseluruhan daripada unsur bumi, air dan kekayaan yang ada dalamnnya yang dipergunakan demi meningkatkan kemakmuran rakyat. Hal ini kemudian dijabarkan lebih lanjut dalam Pasal 1 ayat (3) Undang-undang Nomor 5 Tahun 1960 tentang Peraturan Dasar Pokok-Pokok Agraria (UUPA) yang mengatur politik hukum pertanahan Indonesia yang mana hubungan ini adalah bersifat abadi antara Bangsa Indonesia dengan bumi dan air beserta ruang angkasa sebagaimana yang telah diatur dalam konstitusi dan UUPA. Pasal 2 UUPA menjelaskan bahwa untuk itu Negara diberi hak menguasai pertanahan di Indonesia sebagai suatu usaha untuk menjaga 
agar tanah di Indonesia dapat dipergunakan sebesar-besarnya untuk meningkatkan kemakmuran dan kesejahteraan rakyat.

Negara terkait dengan hak menguasainya berkaitan dengan pengaturan, peruntukan, penggunaan, persediaan dan pemeliharaan tanah termasuk dalam menentukan hubungan antara orang dengan perbuatan hukum terkait dengan tanah. ${ }^{1}$ Salah satu pengaturannya ialah melarang kepemilikan tanah oleh Warga Negara Asing (WNA) sebagaimana diatur Pasal 9 ayat (1) jo. Pasal 21 ayat (1) UUPA dan dipetegas oleh Pasal 26 ayat (2) UUPA yang menyatakan bahwa peralihan hak atas tanah kepada WNA dalam bentuk apapun dilarang dan batal demi hukum serta tanahnya jatuh ke negara. Semua pembayaran yang telah diterima oleh pemilik tidak dapat dituntut kembali, namun hak-hak pihak lain yang membebaninya tetap berlangsung. Adanya larangan itu kemudian disiasati dengan meminjam nama Warga Negara Indonesia (WNI) yang dibungkus dengan melalui berbagai perikatan semu yang dikenal dengan istilah perjanjian nominee.

Maraknya penggunaan perjanjian nominee sebagai sarana kepemilikan tanah oleh WNA didasarkan pada lemahnya penegakan hukum terhadap ketentuan yang melarang kepemilikan tanah oleh WNA. Pasal 26 ayat (2) UUPA yang menyatakan segala bentuk perbuatan hukum peralihan hak atas tanah kepada WNA adalah batal demi hukum, seakan hanya menjadi 'macan kertas' karena tidak adanya upaya penegakan hukum terhadap pelanggaran ketentuan tersebut. Lemahnya aturan hukum ini membuat WNA (dan seringkali juga dibantu oleh WNI) dapat dengan mudah dan tanpa rasa khawatir melakukan penyelundupan hukum melalui perjanjian nominee. Beberapa contoh kasus terkait hal ini antara lain :

1. Kasus Cornelis Jan Dirk Naves vs. Shellisa Kiky Karjadi, dkk di Bali tahun 2010, dengan pelapor Marcel Lothar Manfred Naves secara pidana maupun perdata.

2. Kasus Siti Ristati Isja di Bali tahun 2014, dengan pelapor Robert William Foreman secara pidana maupun perdata.

3. Kasus Robert Pascal vs. Jeremy Thomas di Bali tahun 2014, dengan pelapor Robert Pascal secara pidana maupun perdata. ${ }^{2}$

Berbagai kasus di atas menunjukkan bahwa praktek nominee dalam kepemilikan tanah oleh WNA memang benar terjadi di Indonesia, khusunya di wilayah hukum Pengadilan Negeri Denpasar. Hal ini tentu tidak sejalan dengan politik hukum pertanahan Indonesia yang menginginkan tanah hanya dapat dimiliki oleh WNA agar bisa sebesar-besarnya dipergunakan untuk kemakmuran dan kesejahteraan rakyat Indonesia. Namun, sampai saat ini belum ada politik hukum dari pemerintah untuk memberantas penggunaan nominee dalam kepemilikan tanah oleh WNA. Selain itu, penyelesaian kasus seperti ini juga bisa menimbulkan persoalan hukum yang baru. Apabila diselesaikan melalui hukum pidana, tanah yang menjadi objek kepemilikan oleh WNA tidak dapat dirampas untuk negara karena tidak memenuhi kriteria benda yang dapat dirampas sesuai Pasal 39 dan Pasal 46 ayat (2) Undang-undang Nomor 8 Tahun 1981 tentang Hukum Acara Pidana (KUHAP). Akan tetapi bila diselesaikan melalui jalur perdata yang menganut pembuktian formil, berarti tanah tersebut dianggap sebagai milik seseorang yang namanya tercantum dalam sertifikat. Hal ini

1 Zainuddin dan Ulya, Zaki. "Domein Verklaring dalam Pendayagunaan Tanah di Aceh". Jurnal Hukum Samudra Keadilan 13, No. 1 (2018): 139-152, h. 140.

2 Diolah sendiri oleh penulis berdasarkan data kasus pada tahun 2010 s/d 2014 di wilayah hukum Pengadilan Negeri Denpasar. 
dapat mendorong WNI untuk berbuat curang demi mendapatkan keuntungan dan merugikan WNA.

Berdasarkan pengamatan yang dilakukan, penelitian ini merupakan karya ilmiah orisinal yang berbeda dengan penelitian terdahulu. Beberapa karya ilmiah terdahulu yang terkait antara lain yakni penelitian daripada I Dewa Agung Dharma Jastrawan dan I Nyoman Suyatna tahun 2019 dengan judul "Keabsahan Perjanjian Pinjam Nama (Nominee) oleh Warga Negara Asing dalam Penguasaan Hak Milik Atas Tanah di Indonesia" yang dalam karya ilmiahnya membahas mengenai 1) "Bagaimanakah keabsahan perjanjian pinjam nama (nominee) oleh warga negara asing dalam penguasaan hak milik atas tanah di Indonesia", dan 2) "Bagaimanakah akibat hukum dari perjanjian pinjam nama (nominee) oleh warga negara asing dalam penguasaan hak milik atas tanah di Indonesia". ${ }^{3}$ Penelitian lainnya yang terkait adalah karya ilmiah dari I Wayan Werasmana Sancaya tahun 2013 dengan judul "Kekuatan Mengikat Perjanjian Nominee dalam Penguasaan Hak Milik Atas Tanah" yang dalam karya ilmiahnya membahas mengenai "Bagaimanakah kekuatan mengikat dari perjanjian nominee tersebut terhadap penguasaan hak milik atas tanah oleh warga negara asing?", 4 dan penelitian lainnya yakni karya ilmiah dari Anak Agung Intan Permata Sari dan Ni Ketut Supasti Darmawan tahun 2015 dengan judul "Keabsahan Perjanjian Nominee Kepemilikan Saham dalam Pendirian Perseroan terbatas" yang dalam karya ilmiahnya membahas mengenai "keabsahan perjanjian nominee pemegang saham dalam perseroan terbatas berdasarkan peraturan perundang-undangan yang berlaku di Indonesia". ${ }^{5}$ Berdasarkan uraian tersebut di atas diketahui bahwa terdapat perbedaan antara karya ilmiah yang ditulis oleh penulis dengan karya ilmiah lainnya yang terdahulu, karena tulisan penulis ini menganalisa terkait upaya penegakan hukum terhadap kepemilikan tanah oleh orang asing melalui perjanjian nominee di Indonesia.

\subsection{Rumusan Masalah}

Berdasarkan pada latar belakang tersebut di atas, maka menarik untuk dikaji permasalahan sebagai berikut:

1. Bagaimanakah pengaturan kepemilikan tanah di Indonesia oleh Warga Negara Asing melalui perjanjian nominee?

2. Bagaimanakah penegakan hukum terhadap praktek kepemilikan tanah di Indonesia oleh Warga Negara Asing?

\subsection{Tujuan Penulisan}

Tujuan dilakukan penulisan karya ilmiah ini adalah untuk mengkaji pengaturan terkait kepemilikan tanah di Indonesia oleh orang asing melalui perjanjian nominee dan upaya penegakan hukumnya.

3 Jastrawan, I Dewa Agung Dharma dan Suyatna, I Nyoman. "Keabsahan Perjanjian Pinjam Nama (Nominee) oleh Warga Negara Asing dalam Penguasaan Hak Milik Atas Tanah di Indonesia". Jurnal Kertha Semaya 7, No. 12 (2019): 1-13.

4 Sancaya, I Wayan Werasmana. "Kekuatan Mengikat Perjanjian Nominee dalam Penguasaan Hak Milik Atas Tanah". Jurnal Magister Hukum Udayana 2, No. 3 (2013): 1-21.

5 Sari, Anak Agung Intan Permata dan Darmawan, Ni Ketut Supasti. "Keabsahan Perjanjian Nominee Kepemilikan Saham dalam Pendirian Perseroan terbatas". Jurnal Kertha Semaya 4, No. 2 (2015): 1-5. 


\section{Metode Penelitian}

Penelitian ini menggunakan adalah metode penelitian hukum normatif. Metode ini menempatkan hukum sebagai suatu sistem norma, dengan menelaah kekosongan norma dalam UUPA terkait dengan penegakan hukum kepemilikan hak atas tanah oleh WNA. Pendekatan yang digunakan ialah pendekatan peraturan perundangundangan (statute approach) dan pendekatan konseptual (conseptual approach). Sejalan dengan pernyataan dari I Made Pasek Diantha yang menjelaskan mengenai metode penelitian hukum secara normatif dan dikatakan bahwa metode penelitian secara normatif merupakan salah satu penelitian yang dilakukan dengan menggunakan perspektif internal dan memiliki objek penelitian norma hukum. ${ }^{6}$ Sumber bahan hukum primer penelitian ini adalah peraturan perundang-undangan terkait, sedangkan sumber bahan hukum sekunder bersumber dari buku-buku, hasil penelitian dalam hal ini jurnal maupun tesis dan sumber bahan hukum tertier pada penilitian ini meliputi kamus hukum dan sumber-sumber melalui media internet. Adapun teknik penelusuran bahan hukum menggunakan tehnik studi dokumen dan studi kepustakaan, serta analisis kajian menggunakan analisis kualitatif.

\section{Hasil dan Pembahasan}

\subsection{Perjanjian Nominee dan Kepemilikan Tanah oleh Warga Negara Asing}

Istilah perjanjian nominee terdiri atas dua kata, yaitu perjanjian dan nominee. Menurut Pasal 1313 Burgerlijke Wetbok (BW), perjanjian adalah suatu perbuatan dengan mana satu orang, atau lebih mengikatkan dirinya terhadap satu orang atau lebih. Sejalan dengan hal ini, Subekti menyatakan perjanjian merupakan peristiwa untuk melakukan suatu hal yang mana dua orang ataupun seseorang yang mengikatkan dirinya dengan orang lainnya saling berjanji. Berdasarkan peristiwa hukum perjanjian ini, kemudian timbul suatu hubungan hukum diantara keduanya yang dikenal dengan perikatan, sehingga daripada hubungan hukum tersebut perjanjian dan perikatan yakni perjanjian melahirkan suatu perikatan. Secara prinsip, perikatan paling banyak muncul dari suatu perjanjian dan Perjanjian merupakan sumber terpenting lahirnya perikatan. ${ }^{7}$ Pada hukum perdata nasional, salah satu sumbernya adalah perjanjian, karena menurut doktrin perjanjian mengikat kedua belah pihak, sama seperti undangundang (pacta sun survanda). Oleh karena itu, para pihak yang mengadakan suatu perjanjian tersebut maka perjanjian itu berlaku sebagai hukum yang mengikat bagi hubungan hukum kedua/lebih pihak yang saling mengikatkan diri tersebut, sepanjang tidak bertentangan dengan peraturan perundang-undangan (Pasal 1338 BW).

Berdasarkan Black's Law Dictionary, nominee ialah "one designated to act for another as his representative in a rather limited sense. It is used sometimes to signify an agent or trustee. It has no connotation, however, other than that of acting for another, in representation of another, or as the grantee of another", 8 hal ini bermakna bahwa nominee cenderung menekankan pada seseorang yang mewakili kepentingan pihak lainnya, secara terbatas dan terkadan dikenal dengan istilah wali atau agen. Merujuk pada pengertian

6 Diantha, I Made Pasek. Metodologi Penelitian Hukum Normatif Dalam Justifikasi Teori Hukum (Jakarta: Prenada Media Group, 2017), h. 12.

7 Lahilote, Hasim Sofyan. “Perjanjian Perikatan Jual Beli Perumahan dan Implikasi Yuridisnya Terhadap Para Pihak dalam Perspektif Hukum Perlindungan Konsumen". Jurnal Ilmiah AlSyari'ah 5, No. 1 (2007): 1-11, h. 8.

8 Bryan A. Garner. (1999). Black's Law Dictionary With Guide To Pronunciation. (USA: West Publishing Co, 1999), p. 1072. 
'perjanjian' dan pengertian 'nominee', dapat disimpulkan bahwa yang dimaksud dengan perjanjian nominee adalah suatu perikatan di mana salah satu pihak menunjuk pihak lain untuk bertindak atas nama dirinya dalam menjaga kepentingan atau hakhak pihak yang menunjuk. Penunjukan pihak lain ini dalam masalah kepemilikan tanah biasanya dilakukan dengan cara pinjam nama. Hal ini biasanya dilakukan oleh seseorang atau badan hukum yang secara hukum tidak diperbolehkan menjadi subyek hukum atas suatu hal, kemudian menyiasatinya dengan meminjam nama orang lain yang secara hukum memenuhi syarat sebagai subyek hukum. Orang yang dipinjam namanya (nominee) merupakan pemilik menurut hukum (legal owner), sedangkan yang menunjuk merupakan pemilik asli (beneficiery).

Penggunaan nominee sebagai sarana kepemilikan tanah oleh WNA pada umunya tidak hanya dilakukan dengan satu perjanjian tetapi beberapa. Namun semuanya itu dimaksudkan untuk mengamankan tanah yang dibeli oleh WNA. Menurut Maria S.W. Sumardjo secara umum antara pihak WNA dan WNI perjanjian yang dibuat sebagai sarana kepemilikan tanah oleh WNA ialah sebagai berikut: 9

a. Perjanjian pemilikan tanah dan pemberian kuasa mutlak; pemindahan hak milik atas tanag dan bangunannnya yang dilakukan oleh WNI (nominee) kepada WNA dengan adanya kuasa mutlak yang diberikan kepada WNA tersebut untuk melakukan perbuatan hukum tersebut.

b. Perjanjian Opsional; dalam hal ini WNI memberi opsi guna melaksanakan pembilian bidang tanah dan bangunan yang merupakan hak milik dengan WNA sebagai penyedia dana untuk pembeliannya tersebut.

c. Perjanjian Sewa Menyewa; dalam perjanjian ini pihak WNI menyewakan tanah kepada pihak WNA berdasarkan jangka waktu pemakaian yang dibutuhkan oleh WNA (jangka waktunya tergantung kehendak pihak WNA).

d. Kuasa Menjual; pihak WNI memberikan kuasa mutlak kepada WNA sehingga WNA bisa melakukan perbuatan hukum berupa jual beli tanah dan bangunan.

e. Hibah Wasiat; dalam perjanjian ini Pihak WNI menghibahkan tanah dan bangunan atas namanya kepada pihak WNA.

Perwujudan dari perjanjian nominee pada umumnya memang tidak bisa hanya dalam bentuk satu perjanjian saja tetapi terdiri dari beberapa perjanjian yang hakekatnya merupakan satu paket perjanjian. Satu paket perjanjian itu diimaksudkan untuk memberikan segala kewenangan kepada WNA beneficiary berlaku sebagai pemilik atau yang berhak atas hak milik daripada bidang tanah berdasarkan ketentuan hukum yang berlaku di Indonesia yang sesungguhnya tidak dapat dimiliki. ${ }^{10} \mathrm{Hal}$ ini menunjukkan bahwa perjanjian nominee pada hakekatnya merupakan penyelundupan hukum karena perjanjian tersebut seolah-olah tidak menyalahi peraturan perundangundangan yang berlaku. Padahal isi dari perjanjian aquo dimaksudkan untuk memindahkan tanah kepada WNA. Sementara Pasal 26 ayat (2) UUPA menyatakan adalah batal demi hukum segala bentuk peralihan (perbuatan hukum) kepada orang asing yang secara langsung ataupun sebaliknya dengan maksud untuk mengalihkan hak kepemilikan atas suatu bidang tanah.

9 Hadi, Abd dan Afiyah, Siti. "Perjanjian Nominee Dalam Kaitannya Dengan Kepatian Hukum Bagi Pihak Pemberi Kuasa Ditinjau Dari Undang-Undang Pokok Agraria dan Undang-Undang Kewarganegaraan". Jurnal Ummul Qura XII, No. 2 (2018): 105-122, h. 119.

10 Saputri, Andina Damayanti. "Perjanjian Nominee Dalam Kepemilikan Tanah Bagi Warga Negara Asing yang Berkedudukan di Indonesia (Studi Putusan Pengadilan Tinggi Nomor: 12/PDT/2014/PT/DPS)". Jurnal Repertorium II, No. 2 (2015): 96-104, h. 97. 
Penyelundupan hukum melalui praktek nominee ini kemudian dipilih oleh WNA mengingat dalam peraturan yang berlaku di Indonesia sifatnya masih terbatas, sehingga mereka tidak dapat berinvestasi secara leluasa. Padahal, pembatasan tersebut memang disengaja dibuat guna melindungi kedaulatan bangsa Indonesia dan dalam rangka menggunakan tanah Indonesia untuk kemakmuran dan kesejahteraan rakyat Indonesia. Pembatasan itu dilakukan dalam rangka menjalankan amanat Pasal 33 UUD 1945. Untuk itu, WNA harus mentaati sistem hukum Indonesia ketika mereka hendak menanamkan investasinya di Indonesia. Bila tidak mengikuti aturan yang ada, mereka tidak akan mendapatkan perlindungan dan jaminan kepastian hukum.

\subsection{Penegakan Hukum Terhadap Praktek Kepemilikan Tanah Indonesia oleh Warga Negara Asing}

Salah satu kelemahan UUPA terkait larangan kepemilikan tanah oleh WNA adalah tidak adanya ketentuan yang mengatur permohonan batal demi hukum atas tindakan peralihan (perbuatan hukum) dengan maksud untuk mengalihkan hak kepemilikannya atas tanah baik secara langsung ataupun sebaliknya kepada orang asing. Hal inilah yang membuat eksistensi perjanjian nominee terkait kepemilikan tanah Indonesia oleh WNA masih banyak tejadi di Indonesia khususnya di daerah-daerah wisata. Memang Pasal 26 ayat (2) UUPA perbuatan yang demikian itu batal demi hukum (null and void) yang bermakna bahwa:

a. Perbuatan hukum itu dianggap tidak pernah ada (never existed) sejak semula;

b. Perbuatan hukum tersebut tidak mempunyai kekuatan dan akibat hukum; dan

c. Perbuatan hukum tersebut sejak semula tidak dapat dilaksanakan. ${ }^{11}$

Artinya memang tidak ada kewajiban dari para pihak untuk mengajukan pembatalan atas perjanjian yang batal demi hukum. Namun pada yang sisi lain, suatu perjanjian yang batal demi hukum secara prinsip haruslah mampu memberikan posisi hukum bagi para pihak kembali pada keadaannya yang semula, seolah-olah perjanjian tersebut tidak pernah terjadi atau ada. ${ }^{12}$

Doktrin di atas bila diterapkan dalam perjanjian nominee terkait kepemilikan tanah oleh WNA bemakna bahwa apabila pengadilan memutuskan perjanjian tersebut batal demi hukum, maka konsekuensi logisnya adalah tidak boleh ada salah satu pihak yang dirugikan. Hakim berperan tidak hanya menyatakan perjanjian tersebut batal demi hukum tetapi juga harus memerintahkan untuk mengambil tindakan-tindakan yang mengembalikan hak-hak para pihak kepada keadaan semula. ${ }^{13}$ Namun hal yang demikian itu tidak bisa diterapkan dalam perjanjian nominee terkait kepemilikan tanah oleh WNA. Sebab pada umumnya kedua belah pihak yang terlibat sama-sama diuntungkan sehingga tidak mungkin memperkarakannya ke pengadilan. Praktek yang demikian ini baru muncul menjadi persoalan hukum bila salah satu pihak ada yang curang dan merugikan pihak yang lainnya. Sepanjang keduanya diuntungkan, maka kepemilikan tanah oleh WNA dengan meminjam nama WNI akan tetap terjadi.

Apabila ada para pihak yang curang dan terpaksa harus di bawah ke pengadilan, pada umumnya penyelesaiannya cenderung merugikan salah satu pihak, khusunya

11 Harahap, M. Yahya. (2000). Pembahasan Permasalahan dan Penerapan KUHAP: Pemeriksaan Sidang Pengadilan, Banding, Kasasi, dan Peninjauan kembali. (Jakarta: Sinar Grafika, 2000), h. 385.

12 Nindyo Pramono. (2010). "Problematika Putusan Hakim dalam Perkara Pembatalan Perjanjian". Jurnal Mimbar Hukum 22, No. 2 (2010): 224-233, h. 231.

13 Ibid. 
WNA selaku beneficiary. Sebab hakim pada umumnya menganggap tanah tersebut sebagai milik WNI yang namanya dipinjam dalam sertifikat selaku pemilik secara hukum (legal owner). Hal yang demikian ini tentu dapat mendorong para WNI yang namanya dipinjam pakai untuk berbuat curang sehingga dapat mengurangi kepercayaan WNA terhadap sistem hukum Indonesia. Selain itu, hal yang demikian itu juga akan menimbulkan benturan antara keadilan, kemanfaatan dan kepastian hukum. Gustav Radbruch dengan teori tujuan hukum mengemukakan bahwa apabila terjadi ketegangan antara ketiga nilai tersebut maka keputusannya adalah kembali pada hati nurani. ${ }^{14}$ Dalam hal ini, maka hakim mempunyai peranannya yang penting mengingat dalam peraturan perundang-undangan perjanjian nominee tidak dikenal dan diatur pada sistem hukum eropa kontinental seperti di Indonesia.

Terkait persoalan di atas, maka negara harus berperan aktif dalam memberantas praktek penguasaan tanah oleh WNA melalui upaya penegakan hukum yang mampu menjamin terwujudnya keadilan, kemanfaatan dan kepastian hukum. Peran aktif Negara tersebut juga untuk menjalankan amanat konstitusi dan UUPA yang menganggap hubungan antara Bangsa Indonesia dengan bumi, air, serta ruang angkasa yang sifat hubungannya adalah bersifat abadi. Untuk itu, Negara perlu memberikan kewenangan kepada salah satu organ Negara untuk mewakili Negara dan kepentingan umum mengajukan pembatalan demi hukum praktek penguasaan tanah oleh WNA yang dilakukan melalui perjanjian nominee. Hal yang demikian itu harus didahului dengan melakukan amandemen terhadap ketentuaan dalam UUPA dengan menambahkan ketentuan pembatalan segala bentuk perbuatan hukum yang dimaksudkan guna memindahkan kepemilikan tanah yang dilakukan oleh WNI dan orang asing.

Selanjutnya terkait dengan organ Negara yang selayaknya diberi kewenangan untuk mewakili Negara mengajukan permohonan batal demi hukum perjanjian nominee dalam kepemilikan tanah oleh WNA, maka perlu dikaji organ Negara yang selama ini bertindak sebagai wakil negara. Dalam sejarah penegakan hukum di Indonesia, satu-satunya pejabat yang bisa mewakili negara dalam proses peradilan pidana maupun perdata ialah jaksa, dalam perkara pidana jaksa disebut Jaksa Penuntut Umum (JPU), sedangkan dalam perkara perdata disebut Jaksa Pengacara Negara (JPN)). Istilah pengacara negara ini adalah terjemahan dari landsadvocaten yang tercantum dalam Staatblad 1922 No. 522 tentang tentang Vertegenwoordige (keterwakilan) van den Lande in Rechten. ${ }^{15}$ Pasal 2 Staatblad 1922 No. 522 mengatur bahwa "dalam suatu proses (atau sengketa) yang ditangani secara perdata, maka bertindak untuk pemerintah sebagai penanggung jawab negara di pengadilan adalah opsir justisi atau jaksa". ${ }^{16}$

Peraturan tersebut, memang berlaku pada zaman kolonial namun sampai saat ini belum ada peraturan yang mencabutnya. Sementara Pasal II Aturan Peralihan UUD 1945 menyatakan segala peraturan dan badan hukum yang berlaku pada zaman

14 Sa'adah, Nabitatus. "Kebijakan Pengampunan Pajak (Tax Amnesty) Berdasarkan Keadilan yang Mendukung Iklim Investasi Indonesia". Jurnal Masalah-Masalah Hukum 46, No. 2 (2017): 182-189, h. 185.

15 Yusuf, Muhammad, et.all. "Kedudukan Jaksa sebagai Pengacara Negara dalam Lingkup Perdata dan Tata Usaha Negara". Jurnal Yustika: Media Hukum dan keadilan 21, No. 2 (2019): 12-27, h. 13.

16 HukumOnline.com. (2014). Bahasa Hukum: Jaksa Pengacara Negara. Retrieved from https://www.hukumonline.com/berita/baca/lt53670c63bfe50/bahasa-hukum--jaksapengacara-negara, diakses 15 September 2020. 
kolonial masih tetap berlaku sepanjang belum ada aturan yang mencabutnya. Hal ini bermakna staatsblad aquo masih tetap berlaku sebagaimana berlakunya Herziene Indonesische Reglement (HIR) dan Rechtsreglement voo de Buitengewesten (RBG) sebagai hukum acara perdata di Indonesia. Menurut Martin Basiang, kedudukan jaksa sebagai seorang pengacara negara tidak serta merta membuat seluruh jaksa bisa menjadi JPN, hanya kepada jaksa yang secara struktural dan fungsional melaksanakan tugas perdata dan tata usaha negara. ${ }^{17}$

Saat ini kewenangan jaksa dalam penegakan hukum perdata perdata diatur dalam Pasal 30 ayat (1), ayat (2) dan ayat (3) Undang-Undang Nomor 16 Tahun 2004 tentang Kejaksaan RI (UU Kejaksaan) yang membagi tugas dan wewenang umum kejaksaan yakni dalam bidang pidana, bidang perdata dan bidang tata usaha negara, bidang ketertiban dan bidang ketenteraman umum. Pada bidang perdata dan tata usaha negara, dengan kuasa khusus kejaksaan dapat bertindak baik di dalam atau di luar pengadilan untuk dan atas nama negara atau pemerintah. Selain diatur dalam UU Kejaksaan, kewenangan kejaksaan di bidang perdata juga diatur dalam undangundang sektoral, seperti pembatalan perkawinan diatur dalam UU Perkawinan; pembatalan merk diatur dalam UU Merk; pembatalan paten diatur dalam UU Paten; pembubaran Perseran Terbatas diatur dalam UU Perseroan Terbatas; dan lain-lain.

Eksistensi JPN semakin jelas pengaturannya dengan dikeluarkannya Peraturan Presiden Nomor 29 Tahun 2016 tentang Perubahan Atas Peraturan Presiden Nomor 38 Tahun 2010 tentang Organisasi dan Tata Kerja Kejaksaan Republik Indonesia (Perpres 29/2016). Pasal 24 ayat (2) Perpres aquo menyatakan:

Lingkup bidang perdata dan tata usaha negara meliputi penegakan hukum, bantuan hukum, pertimbangan hukum dan tindakan hukum lain kepada negara atau pemerintah, meliputi lembaga/badan negara, lembaga/instansi pemerintah pusat dan daerah, Badan Usaha Milik Negara/Daerah di bidang perdata dan tata usaha negara untuk menyelamatkan, memulihkan kekayaan negara, menegakkan kewibawaan pemerintah dan negara serta memberikan pelayanan hukum kepada masyarakat.

Pada hakekatnya dapat dipahami bahwa tugas dan kewenangan JPN di atas adalah dalam rangka memelihara ketertiban umum dan menghindari terjadinya suatu pelanggaran agar terciptanya kepastian hukum di tengah-tengah masyarakat benarbenar dapat diwujudkan. Hal ini dapat dilihat dari alasan yang dapat dijadikan dasar oleh jaksa untuk melaksanakan berbagai kewenangannya di atas, yang pada intinya ialah karena adanya pelanggaran terhadap kepentingan umum, melanggar kesusilaan dan norma agama, merugikan kepentingan masyarakat, merugikan kepentingan negara, melanggar peraturan perundang-undangan dan berbagai alasan sejenisnya. Kejaksaan dalam hal ini akan bertindak atas nama negara dalam rangka mewakili kepentingan umum untuk menegakkan hukum dan perundang-undangan demi terciptanya keadilan dan kepastian hukum, karena secara historis jaksa memang diberi kewenangan sebagai wakil negara atau yang sekarang dikenal dengan sebutan Jaksa Pengacara Negara. Selain itu secara historis jaksa juga diberi kewenangan untuk memelihara ketertiban dan ketentraman umum sebagaimana diatur dalam Pasal 181 Reglement op de rechtelijke organisatie en het beleid der justitie (Staatsblad 1847 No. 23 tentang Organisasi Peradilan dan Kebijaksanaan Justisi).

Secara internal pengaturan terkait JPN diatur lebih lanjut dalam Peraturan Jaksa Agung RI (Perja) Nomor: Per-009/A/JA/01/2011 tentang Organisasi dan Tata Kerja

17 Ibid. 
Kejaksaan RI; Perja Nomor: Per- 018/A/J.A/07/2014 tentang Standar Operasional Prosedur pada JAMDATUN; dan Perja Nomor: Per-025/A/JA/11/2015 tentang Petunjuk Pelaksanaan Penegakan Hukum, Bantuan Hukum, Pertimbangan Hukum, Tindakan Hukum Lain dan Pelayanan Hukum di Bidang DATUN. Berdasarkan ketentuan huruf c butir 4 Lampiran Perja Nomor: Per- 018/A/J.A/07/2014,

Penegakan hukum adalah tugas jaksa pengacara negara untuk mengajukan gugatan atau permohonan kepada pengadilan di bidang perdata sebagaimana ditetapkan oleh peraturan perundang-undangan dalam rangka memelihara ketertiban hukum, kepastian hukum dan melindungi kepentingan negara dan pemerintah serta hak hak keperdataan masyarakat, antara lain: pembatalan perkawinan, pembubaran Perseroan Terbatas dan pernyataan pailit.

Kemudian berdasarkan Bab I huruf f butir 9 dan Bab II huruf a Lampiran Perja Nomor: Per-025/A/JA/11/2015 tentang Petunjuk Pelaksanaan Penegakan Hukum, Bantuan Hukum, Pertimbangan Hukum, Tindakan Hukum Lain dan Pelayanan Hukum di Bidang DATUN, "Penegakan Hukum adalah kegiatan Jaksa Pengacara Negara untuk mengajukan gugatan atau permohonan kepada pengadilan di bidang perdata sebagaimana ditetapkan oleh peraturan perundang-undangan dalam rangka memelihara ketertiban hukum, kepastian hukum, dan melindungi kepentingan Negara dan Pemerintah serta hak-hak keperdataan masyarakat" dan seterusnya terkait wewenang JPN melakukan penegakan hukum melalui gugatan/permohonan ke pengadilan terhadap permasalahan hukum sebagaimana dimaksud dalam peraturan ini.

Berdasarkan rumusan di atas, tugas JPN di bidang perdata ialah dalam rangka memelihara ketertiban hukum; memelihara kepastian hukum; melindungi kepentingan Negara dan Pemerintah; dan melindungi hak-hak keperdataan masyarakat. Ke-empat hal itu, semuanya terdapat dalam tujuan permohonan batal demi hukum perjanjian nominee terkait kepemilikan tanah oleh WNA. Sebab perjanjian nominee dalam kepemilikan tanah oleh WNA pada hakekatnya bertentangan dengan konstitusi dan UUPA yang menentukan sifat abadi hubungan bangsa Indonesa dengan tanah Indonesia dan larangan kepemilikan tanah oleh WNA.

Selain melalui sarana perdata, pemberantasan kepemilikan tanah oleh WNA melalui perjanjian nominee dan pengembalian tanahnya ke Negara, juga dapat dilakukan jaksa melalui sarana pidana. Upaya pidana dapat dilakukan oleh jaksa dengan mengajukan tuntutan agar tanah yang menjadi obyek praktek nominee dikembalikan kepada Negara. Namun bila hakim tidak memutus sesuai isi dari pada tuntutan tersebut, maka JPU perlu melimpahkannya kepada JPN agar diajkan pembatalan demi hokum ke pengadilan perdata. Hal ini diperlukan untuk menghindari ketidakjelasan status tanah dikarenakan status atas tanah tersebut tidak dapat dinyatakan sebagai hak milik WNA. Sementara, bila hakim menyatakan tanah menjadi milik WNI (nominee) karena nama yang tercantum dalam sertifikat adalah nama si-nominee, hal ini juga kurang tepat karena tidak sesuai Pasal 26 ayat (2) UUPA sehingga dapat menimbulkan ketidakpastian hukum dan ketidakadilan karena pada prinsipnya batal demi hukum adalah mengembalikan keadaan seperti keadaan semula sebelum adanya perjanjian.

Penegakan hukum melalui sarana pidana oleh JPU terhadap perjanjian nominee haruslah didahului dengan dilakukannya penyidikan. Pada tahap penyidikan, JPU perlu memberi petunjuk kepada penyidik agar menyita tanah obyek perjanjian nominee agar memudahkan proses penuntutannya. Menurut Pasal 1 angka 16 KUHAP, "Penyitaan adalah serangkaian tindakan penyidik untuk mengambil alih dan atau 
menyimpan di bawah penguasaannya benda bergerak dan atau tidak bergerak, berwujud atau tidak berwujud untuk kepentingan pembuktian dalam penyidikan, penuntutan dan peradilan". Definisi tersebut agak panjang namun pengertian yang terkandung di dalamnya cukup terbatas karena penyitaan hanya dianggap untuk kepentingan pembuktian. Padahal dalam prakteknya, penyitaan bukan hanya untuk kepentingan pembuktian, tetapi juga diperlukan untuk kepentingan beracara pidana yang lainnya, seperti eksekusi. Pelaksanaan penyitaan terlebih dahulu, diharapkan dapat mempermudah proses eksekusi yang dilakukan jaksa terhadap barang atau benda yang terkait dengan tindak pidana. Namun pada sisi yang lain, pengembalian tanah obyek perjanjian nominee ke negara harus memperhatikan ada tidaknya hak-hak pihak lain yang beri'tikad baik atas tanah tersebut.

Pengertian penyitaan yang terbatas dalam KUHAP Indonesia, berbeda dengan pengertian penyitaan menurut KUHAP Belanda. Pasal 134 Ned. Sv. memberikan definisi penyitaan (imbeslagneming) lebih pendek namun dengan pengertian yang lebih luas. Terjemahan dari pasal tersebut kurang lebih ialah "dengan penyitaan sesuatu benda diartikan pengambilalihan atau penguasaan benda itu guna kepentingan acara pidana". ${ }^{18}$ Jadi bukan hanya dibatasi untuk kepentingan pembuktian, tetapi untuk kepentingan beracara pidana secara umum. ${ }^{19}$ Bahkan di dalam Pasal 94 Ned. Sv. ditentukan bahwa "benda yang dapat disita selain yang berguna untuk mencari kebenaran (pembuktian) juga benda-benda yang dapat diputus untuk dirampas, dirusakkan, atau dimusnahkan" ${ }^{20}$ Ketentuan yang hampir sama terdapat dalam Pasal 46 ayat (2) KUHP yang menyatakan:

apabila perkara sudah diputus, maka benda yang dikenakan penyitaan dikembalikan kepada orang atau kepada mereka yang disebut dalam putusan tersebut, kecuali jika menurut putusan hakim benda itu dirampas untuk negara, untuk dimusnahkan atau untuk dirusakkan sampai tidak dapat dipergunakan lagi atau, jika benda tersebut masih diperlukan sebagai barang bukti dalam perkara lain.

Berdasarkan ketentuan tersebut maka penyitaan itu bukan hanya untuk kepentingan pembuktian tetapi juga untuk kepentingan beracara pidana secara keseluruhan sehingga benda yang dapat disita bukan hanya benda yang berguna untuk mencari kebenaran (pembuktian) tetapi juga benda yang dapat diputus untuk dirampas, dirusakkan atau dimusnahkan agar memudahkan eksekusi. Hal ini bermakna bahwa tanah yang menjadi obyek perjanjian nominee sebenarnya juga dapat digunakan untuk menemukan kebenaran materiil. Hal ini karena asal mula terjadinya tindak pidana itu pada dasarnya berkaitan dengan adanya perjanjian nominee, dan untuk itu tanah obyek perjanjian nominee sudah memenuhi syarat untuk dapat dilakukan penyitaan. Apalagi Pasal 26 ayat (2) UUPA menyatakan dengan tegas tanah itu jatuh ke negara. Hanya saja karena selama ini tidak ada mekanisme yang mengaturnya, maka ketentuan tersebut bagaikan macan kertas belaka. Untuk itu, ke depan perlu ada amandemen terhadap berbagai peraturan terkait agar pemberantasan terhadap kepemilikan tanah oleh WNA melalui perjanjian nominee dapat dilaksanakan dengan baik.

18 Hamzah, Andi. Hukum Acara Pidana Indonesia. (Jakarta : Sinar Grafika, 2005), h. 4.

19 Ibid.

20 Eddy Rifai dan Rakhmat Triyono. "Eksekusi Barang Rampasan Hasil Tindak Pidana Kehutanan Pasca Putusan Mahkamah Agung Nomor 021/PUU-III/2005". Jurnal Konstitusi 12, No. 1 (2015): 43-56, h. 46. 


\section{Kesimpulan}

Pengalihan hak milik atas tanah yang dilakukan oleh WNI kepada orang asing dalam bentuk tindakan apapun (langsung ataupun sebaliknya) adalah tindakan penyelundupan hukum. Penyelundupan hukum melalui praktek nominee banyak dipilih oleh WNA karena adanya pembatasan dalam peraturan perundang-undangan Indonesia, membuat mereka tidak dapat berinvestasi secara leluasa. Namun, di sisi pengaturan Pasal 26 ayat (2) UUPA menyatakan adalah batal demi hukum segal sesuatu tindakan baik langsung ataupun sebaliknya dengan tujuan mengalihkan hak kepemilikannya atas tanah kepada WNA. Upaya penegakan hukum terhadap kepemilikan tanah Indonesia oleh WNA dengan menggunakan nama WNI melalui perjanjian pinjam nam (nominee) perlu segera dilaksanakan secara tegas dan konsisten. Oleh karena itu perlu ada amandemen terhadap peraturan perundang-undangan terkait, khususnya dengan UUPA, dengan memberikan kewenangan kepada JPN selaku organ negara untuk mengajukan permohonan batal demi hukum perjanjian nominee dan mengembalikan obyek tanahnya ke Negara. Selain melalui sarana perdata hal ini juga bisa dilakukan melalui sarana pidana dengan mengajukan tuntutan agar tanah yang menjadi obyek perjanjian nominee dikembalikan ke Negara. Upaya penegakan hukum oleh kejaksaan ini perlu dilakukan guna menjamin perlindungan dan memberikan rasa keadilan bagi para pihak tanpa harus merugikan hak-hak daripada para pihak yang terlibat dalam praktek perjanjian nominee tersebut. Selain itu upaya penegakan hukum ini dilakukan pula guna menjamin kepastian hukum daripada ketentuan Pasal 26 ayat (2) UUPA yang secara tegas menyatakan segala bentuk perbuatan hukum yang dimaksudkan untuk memindahkan kepemilikan tanah kepada WNA adalah batal demi hukum dan tanahnya jatuh ke negara.

\section{DAFTAR PUSTAKA}

\section{Buku-Buku}

Bryan A. Garner. (1999). Black's Law Dictionary With Guide To Pronunciation. (USA: West Publishing Co, 1999).

Diantha, I Made Pasek. Metodologi Penelitian Hukum Normatif Dalam Justifikasi Teori Hukum (Jakarta: Prenada Media Group, 2017).

Hamzah, Andi. Hukum Acara Pidana Indonesia. (Jakarta : Sinar Grafika, 2005).

Harahap, M. Yahya. (2000). Pembahasan Permasalahan dan Penerapan KUHAP: Pemeriksaan Sidang Pengadilan, Banding, Kasasi, dan Peninjauan kembali. (Jakarta: Sinar Grafika, 2000).

\section{Jurnal}

Eddy Rifai dan Rakhmat Triyono. “Eksekusi Barang Rampasan Hasil Tindak Pidana Kehutanan Pasca Putusan Mahkamah Agung Nomor 021/PUU-III/2005". Jurnal Konstitusi 12, No. 1 (2015): 43-56.

Hadi, Abd dan Afiyah, Siti. "Perjanjian Nominee Dalam Kaitannya Dengan Kepatian Hukum Bagi Pihak Pemberi Kuasa Ditinjau Dari Undang-Undang Pokok Agraria dan Undang-Undang Kewarganegaraan". Jurnal Ummul Qura XII, No. 2 (2018): 105-122. 
Jastrawan, I Dewa Agung Dharma dan Suyatna, I Nyoman. “Keabsahan Perjanjian Pinjam Nama (Nominee) oleh Warga Negara Asing dalam Penguasaan Hak Milik Atas Tanah di Indonesia". Jurnal Kertha Semaya 7, No. 12 (2019): 1-13.

Lahilote, Hasim Sofyan. "Perjanjian Perikatan Jual Beli Perumahan dan Implikasi Yuridisnya Terhadap Para Pihak dalam Perspektif Hukum Perlindungan Konsumen". Jurnal Ilmiah Al-Syari'ah 5, No. 1 (2007): 1-11.

Nindyo Pramono. (2010). "Problematika Putusan Hakim dalam Perkara Pembatalan Perjanjian". Jurnal Mimbar Hukum 22, No. 2 (2010): 224-233.

Sa'adah, Nabitatus. "Kebijakan Pengampunan Pajak (Tax Amnesty) Berdasarkan Keadilan yang Mendukung Iklim Investasi Indonesia". Jurnal Masalah-Masalah Hukum 46, No. 2 (2017): 182-189.

Sancaya, I Wayan Werasmana. "Kekuatan Mengikat Perjanjian Nominee dalam Penguasaan Hak Milik Atas Tanah". Jurnal Magister Hukum Udayana 2, No. 3 (2013): 1-21.

Saputri, Andina Damayanti. “Perjanjian Nominee Dalam Kepemilikan Tanah Bagi Warga Negara Asing yang Berkedudukan di Indonesia (Studi Putusan Pengadilan Tinggi Nomor: 12/PDT/2014/PT/DPS)". Jurnal Repertorium II, No. 2 (2015): 96-104.

Sari, Anak Agung Intan Permata dan Darmawan, Ni Ketut Supasti. "Keabsahan Perjanjian Nominee Kepemilikan Saham dalam Pendirian Perseroan terbatas". Jurnal Kertha Semaya 4, No. 2 (2015): 1-5.

Yusuf, Muhammad, et.all. “Kedudukan Jaksa sebagai Pengacara Negara dalam Lingkup Perdata dan Tata Usaha Negara". Jurnal Yustika: Media Hukum dan keadilan 21, No. 2 (2019): 12-27.

Zainuddin dan Ulya, Zaki. "Domein Verklaring dalam Pendayagunaan Tanah di Aceh". Jurnal Hukum Samudra Keadilan 13, No. 1 (2018): 139-152.

\section{Peraturan Perundang-Undangan}

Indonesia, Undang-Undang Dasar Negara Republik Indonesia Tahun 1945

Moeljatno. (2011). Kitab Undang-Undang Hukum Pidana. Jakarta : Bumi Aksara

Undang-Undang Nomor 8 Tahun 1981 tentang Hukum Acara Pidana, (Lembaran Negara Republik Indonesia Tahun 1981 Nomor 76, Tambahan Lembaran Negara Republik Indonesia Nomor 3258).

Undang-Undang Nomor 5 Tahun 1960 tentang Peraturan Dasar Pokok-Pokok Agraria, (Lembaran Negara Republik Indonesia Tahun 1960 Nomor 104, Tambahan Lembaran Negara Republik Indonesia Nomor 2043).

Undang-Undang Nomor 16 Tahun 2004 tentang Kejaksaan Republik Indonesia, (Lembaran Negara Republik Indonesia Tahun 2004 Nomor 67, Tambahan Lembaran Negara Republik Indonesia Nomor 4401).

Peraturan Presiden Nomor 29 Tahun 2016 tentang Perubahan Atas Peraturan Presiden Nomor 38 Tahun 2010 tentang Organisasi dan Tata Kerja Kejaksaan Republik Indonesia. 
Peraturan Jaksa Agung Nomor: Per-009/A/JA/01/2011 tentang Organisasi dan Tata Kerja Kejaksaan Republik Indonesia.

Peraturan Jaksa Agung RI Nomor: Per- 018/A/J.A/07/2014 tentang Standar Operasional Prosedur pada JAMDATUN.

Peraturan Jaksa Agung RI Nomor: Per-025/A/JA/11/2015 tentang Petunjuk Pelaksanaan Penegakan Hukum, Bantuan Hukum, Pertimbangan Hukum, Tindakan Hukum Lain dan Pelayanan Hukum di Bidang DATUN.

\section{Internet}

hukumonline.com. (2014). Bahasa Hukum: Jaksa Pengacara Negara. Retrieved from https://www.hukumonline.com/berita/baca/lt53670c63bfe50/bahasa-hukum-jaksa-pengacara-negara, diakses 15 September 2020. 